Resumo de Tese

\title{
Trabalho informal, precário ou perigoso: abordagem de ação coletiva por uma equipe de Saúde da Família em Uberaba
}

These Abstract

\author{
Informal, precarious or dangerous work: collective approach \\ by a Femily Health Team in Uberaba.
}

Aidê Amabile Coêlho dos Santos

\section{Resumo}

A globalização força as relações de trabalho a tornarem-se mais flexíveis, surgindo um grande contingente de profissionais desprotegidos, ignorados pelas empresas, sem direito à assistência e ao controle de sua saúde. A intenção de prestar assistência integral ao trabalhador informal em condições precárias ou perigosas conduziu-se um estudo descritivo prospectivo de base populacional investigando-se o tempo trabalhado e acidentes ou doenças relacionadas com o trabalho durante quatro meses mediante visitas semanais pelos Agentes Comunitários de Saúde da Equipe. Aplicou-se instrumento de coleta de dados elaborado em projeto-mãe para outra cidade após adaptação às condições locais. Observou-se que 62,1\% dos trabalhadores eram do sexo feminino; 43,9\% tinham entre 35 e 50 anos; 55,6\% trabalhavam por conta própria; 39,9\% eram empregados e 8,4\% dos entrevistados pagavam a Previdência Social. O motivo de ingresso no setor informal foi o desemprego para $44,1 \%$ enquanto $24,6 \%$ buscavam melhores rendimentos. A jornada diária de trabalho foi de 8 horas/dia para 39,7\%; o trabalho durante 7 dias por semana foi referido por 31,6\%; 7,0\% referiram a ocorrência de pelo menos um acidente no local de trabalho e 69,0\% dos entrevistados alegaram conhecer uma pessoa em perigo em seus locais de trabalho. A contribuição do planejamento para a organização do sistema de saúde e, conseqüentemente, a assistência à saúde dos trabalhadores é valiosa, envolvendo gestores até os trabalhadores das equipes de saúde. Faz-se necessário à inserção da saúde do trabalhador na saúde coletiva, ambos como campos de conhecimento complexos, que busquem a produção de saúde para a coletividade. Palavras - chave: Saúde pública, Acidentes de trabalho, Saúde do trabalhador, Planejamento em saúde.

Dissertação de Mestrado 2006 Universidade Estadual De Campinas - Saúde Coletiva

Disponivel para consulta em:

http:// servicos.capes.gov.br/capesdw/resumo.html?idtese=20062618233003017058P4

Palavras-chave: Saúde Coletiva; Acidente de

Trabalho; Saúde do Trabalhador.
Key Words: Collective Health; Work

Accident; Worker Health. 